\title{
The primacy of knowledge in the making of shifting modern global imaginaries
}

\author{
Sabelo J. Ndlovu-Gatsheni ${ }^{1}$
}

Accepted: 6 February 2021 / Published online: 20 February 2021

(C) The Author(s) 2021

\section{Introduction: Does Epistemology Frame Ontology?}

Reading Isaac Kamola's Making the World Global: U. S. Universities and the Production of the Global Imaginary (2019) provoked the long-standing questions of the relationship between knowledge and reality (as an imaginary) and indeed between institutions and intellectual/ideological productions. Some understood this question of 'epistemology-ontology' as a sort of chicken-egg dialectic because even though knowledge actively creates domains of politics, economy, and society (defined here as epistemic creations), it is also shaped by politics, economy, and knowledge. Increasingly, scholars such as Boaventura de Sousa as well as Walter D. Mignolo and Catherine E. Walsh are underscoring how epistemology frames ontology. For example, Santos (2018, p. 27) posited that 'social scientific knowledge invented much of what it described as existing; such an invention became part of social reality as it got embedded in the ways people behave and perceive social life.' The same logic is expressed by Mignolo and Walsh (2018, p. 35) who openly state that 'Ontology is made of epistemology' and elaborated that 'It is knowledge weaved around concepts such as politics and economy that is crucial for decolonial thinking, and not politics and economy as transcendental entities.'

These entry points are very necessary and relevant to any appraisal of Kamola's book because it delves into institutions and their products that can be read as imaginaries (formulated and articulated worldviews and modes of world-sensing across space and time). Thus, reading Kamola's book provoked deeper and broader questions about modernity as the foundational discursive terrain encasing Renaissance, Reformation, Enlightenment, Industrialism, Capitalism, and Imperialism (Colonialism/Neo-Colonialism/Globalization), the modern world system and its shifting global orders as epistemic creations as well as seeking to understand the roots of modern systemic and institutional challenges and problems.

Sabelo J. Ndlovu-Gatsheni

Sabelo.ndlovu-gatsheni@uni-bayreuth.de

1 Epistemologies of the Global South, University of Bayreuth, Bayreuth, Germany 
At the core of the 'epistemology-ontology' dialectic is the broader politics of 'governing what it means to be a human being' as a key component of modern world imaginary (Ndlovu-Gatsheni, 2018; Ndlovu-Gatsheni, 2020a, b). The consequence was the present resilient social classification of human population and its racial hierarchization in accordance with invented differential ontological densities. The decolonization of the twentieth century as well as the liberal discourses of democracy and human rights that assumed a normative status after the end of the Cold War failed to deal effectively with what Maldonado-Torres (2007) termed 'coloniality of being.' Inevitably, the current insurgent and resurgent planetary decolonization galvanized by the Rhodes Must Fall and Black Lives Matter movements have returned to that unfinished if not incomplete struggle for re-humanization of the dehumanized/remembering of the dismembered (see Ngugi wa Thiong'o 2009).

\section{Current Theoretical/Epistemic Conjuncture}

Epistemologically speaking, Kamola's work emerged within a context of an epistemic rupture and what the Indian scholar Nigam (2020) understood as a veritable earthquake in the field of theory and philosophy symbolized by such interventions as 'decolonial option,' 'decolonial theory,' 'epistemic disobedience,' 'delinking,' 'epistemologies of the South,' 'theory from the South,' and 'epistemic freedom' among many other aspects of the present theoretical conjuncture. There are clear efforts not just about critique but also epistemic reconstitution. The current theoreti$\mathrm{cal} /$ epistemic conjuncture was well captured by the leading sociologist of knowledge Wallerstein (2004, p. 58):

I believe that we live in a very exciting era in the world of knowledge, precisely because we are living in a systemic crisis that is forcing us to reopen the basic epistemological questions and look to structural reorganizations of the world of knowledge. It is uncertain whether we shall rise adequately to the intellectual challenge, but it is there for us to address. We engage our responsibility as scientists/scholars in the way in which we address the multiple issues before us at this turning point in our structures of knowledge.

Kamola has joined others in rising adequately to the intellectual and indeed existential challenge highlighting how the Cold War and the post-Cold War neoliberal ideas interpellated intellectual productions and reinvented the modern world in the image of capital, the nation state, and the highly contested 'global' (always undercut by vicissitudes of deterritorialization and reterritorialization, waning sovereignty, and rising walled states to borrow ideas from Wendy Brown). What is even more difficult is to map out the character of the envisaged genuinely decolonized world. There is no doubt that a decolonial imaginary is upon us. Rethinking and even unthinking of issues is at play. The painstaking processes of unlearning and relearning are afoot. Naming the imagined decolonial world is in the making. Samir Amin wrote about a 'polycentric world.' Ngugi wa Thiong'o gave us the name 'globalectics' as an imaginary. The Latin American decolonial theorists speak of 
a 'pluriversity.' Some Asian scholars prefer the term 'transversity.' Those who are concerned about Africa in the modern world imaginary have also coined interesting utopic registers of the future. Achille Mbembe pushes for 'Afropolitianism.' Felwine Sarr speaks of 'Afrotopia.' What is common among these decolonial imaginaries is recognition of plurality and ecologies of re-existence free from asymmetrical power relations as well as race and gender as organizing principles of the modern paradigm of difference. Back to Kamola's work, it is important to frame it historically by pulling back into history before charging into the present.

\section{Framing Kamola's Interventions: Empire as a Major Discursive Framework of Modern World Imaginaries}

While Kamola's analysis concentrated on two post-1945 moments of the 'Cold War university' and the modern world imaginary organized around a system of modern states and the Washington Consensus and neoliberal imaginary of the modern world as a big commercial and indeed corporate market, his analysis can be drawn back to the initial imaginary of 'the colonizer's model of the world' that was clearly articulated by Blaut (1993). At the very center of the 'colonizer's model of the world' emerged the empire. Regarding the importance of the empire, the South African economist Terreblanche (2014, p. 10) correctly posited that:

We cannot understand the challenges of our time without understanding the ways in which 500 years of Western empire building, often with the complicity of the elites of the Restern World, have shaped our world into the deeply unequal and gratuitously unjust place that it is today.

The making of the world global and the global imaginary have deep roots in the unfolding of Euromodernity and Western empire building politics. Here, I will link and locate Kamola's work within the framework of the cognitive empire and what the historian Gildea (2019) termed the 'global financial republic' as an 'empire of the mind' (see also Ndlovu-Gatsheni, 2020a). In the first instance, what he terms 'the world of higher education' and the universities is the very domain in which the cognitive empire is reproduced. The philanthropic organizations, government agencies, professional associations, and international financial institutions form part of the global financial republic. The cognitive empire carries forward the immanent logic of coloniality. It survives through an invasion of the mental universe of its victims so as to reproduce them in accordance with its desired logics and imaginaries. Ngugi wa Thiong'o (1986, p. 15) highlighted how the cognitive empire operates through detonation of 'a cultural bomb' at the center of the universe, and he provided the most comprehensive summary of its effects:

The effect of the cultural bomb is to annihilate a people's belief in their names, their languages, in their environment, in their heritage of struggle, in their unity, in their capacities and ultimately in themselves. It makes them see their past as one wasteland of non-achievement and it makes them want to distance themselves from the wasteland. It makes them want to identify with that which 
is furthest removed from themselves; for instance, with other peoples' languages rather than their own. It makes them identify with that which is decadent and reactionary, all those forces which would stop their own springs of life. It even plants serious doubts about the moral rightness of struggle. Possibilities of triumph or victory are seen as remote, ridiculous dreams. The intended results are despair, despondency and a collective death wish. Amidst this wasteland which it created, imperialism presents itself as the cure.

Kamola's work alerts us to the post-1945 unfolding of US cognitive empire and financial republic and how in inextricably intertwined combinations a global imaginary with the USA at the center was invented. He correctly identifies what he terms the 'Cold War university' as a storm-trooping institution of reproduction of US global hegemony. Besides institutions, Kamola identified even individual scholarscum-bureaucrats who were active in the making of the modern world in the image of the interests of the US empire. What is emerging is how the USA invested resources in shaping how the post-1945 world was known as that of the dominance of nation states and how the post-Cold War would be known as a mega-commercial market. Disciplinarily speaking, this entailed a shift from area studies to global studies. Thus, one can easily notice the importance of thinking through these issues from the perspective of the cognitive empire and its financial republic - in combination they constitute 'empires of the mind.'

\section{Concluding Reflections}

Good books always provoke numerous questions and generate new debates. This is true of Kamola's Making the World Global. It is an important book with a guaranteed long shelf life and indeed virtual space life. His theoretical framework is part of emerging works that seek to bring Marxism and Decoloniality together, with Marxism remaining the best science of understanding the operations of the capitalist system across time and space and Decoloniality being the best mode of diagnosis of global coloniality and reconstitution of knowledge as it brings the questions of epistemology and existential life together. Kamola's focus on the American academy took us directly to a new understanding of the American Empire not in its physicality and commerciality but in its cognitive dimensions which anchor and indeed enable all other dimensions of its global coloniality. What is beautiful about Kamola's interventions is that they reveal that such cogs of the US financial republic as the World Bank, IMF, and many others are not only to be understood as financial institutions; they are also active cognitive sites of reproduction of global capital and US Empire-compliant knowledge. After reading Kamola's work, no one remains surprised by why universities across the world are experiencing a triple crisis of hegemony, legitimacy, and institutional nature (see Santos, 2017). The students, youth, and progressive intellectuals are rebelling against the cognitive empire, and the university is a correct target because for over centuries it has been a major cog in reproduction of the status quo even though universities have also been sites of radical thinking opposed to the status quo of coloniality. Kamola's conclusion that: 'The 
production of academic knowledge about globalization necessarily involves imagining the world as global. Global imaginaries, however, do not simply emerge from thin air but are themselves produced and reproduced within diverse world' (p. 189) ties very well with my entry point into his work via epistemology framing ontology. His concern with reimagination if not reconstitution of world drawing from ecologies of knowledge is most welcomed and is what is at the center of decolonization of the twenty-first century.

Funding Open Access funding enabled and organized by Projekt DEAL.

Open Access This article is licensed under a Creative Commons Attribution 4.0 International License, which permits use, sharing, adaptation, distribution and reproduction in any medium or format, as long as you give appropriate credit to the original author(s) and the source, provide a link to the Creative Commons licence, and indicate if changes were made. The images or other third party material in this article are included in the article's Creative Commons licence, unless indicated otherwise in a credit line to the material. If material is not included in the article's Creative Commons licence and your intended use is not permitted by statutory regulation or exceeds the permitted use, you will need to obtain permission directly from the copyright holder. To view a copy of this licence, visit http://creativecommons.org/licen ses/by/4.0/.

\section{References}

Blaut, J.M. (1993) The Colonizer's Model of the World: Geographical Diffusion and Eurocentric History. New York and London: The Gilford Press.

de Santos, B.S. (2017) Decolonizing the University: The Challenges of Deep Cognitive Justice. Newcastle Upon Tyne: Cambridge Scholars Publishing.

de Santos, B.S. (2018) The End of the Cognitive Empire: The Coming of Age of Epistemologies of the Global South. Durham and London: Duke University Press.

Gildiea, R. (2019) Empires of the Mind: The Colonial Past and the Politics of the Present. Cambridge: Cambridge University Press.

Kamola, I. (2019) Making the World Global: U. S. Universities and the Production of the Global Imaginary. Durham and London: Duke University Press.

Maldonado-Torres, N. (2007) On coloniality of being: Contributions to the development of a concept. Cultural Studies, 21(2-3): 240-270.

Mignolo, W.D., \& Walsh, C.E. (2018) On Decoloniality: Concepts, Analytics, Praxis. Durham and London: Duke University Press.

Ndlovu-Gatsheni, S.J. (2018) Epistemic Freedom in Africa: Deprovincialization and Decolonization. London and New York: Routledge.

Ndlovu-Gatsheni, S.J. (2020) Decolonization, Development and Knowledge in Africa: Turning over a New Yeaf. London and New York: Routledge.

Ndlovu-Gatsheni, S.J. (2020) The cognitive Empire, politics of knowledge and African intellectual productions: Reflections on struggles for epistemic freedom and resurgence of decolonization of the twenty-first century. Third World Quarterly. https://doi.org/10.1080/01436597.2020.7775487

Ngugi wa Thiong'o (1986) Decolonizing the Mind: The Politics of Language in African Literature. Oxford: James Currey.

Ngugi wa Thiong'o (2009) Re-membering Africa. Nairobi/Kampala/Dar es Salaam: East African Education Publishers.

Nigam, A. (2020) Decolonizing Theory: Thinking Across Traditions. New Delhi/London/Oxford/New York/Sydney: Bloomsbury.

Terreblanche, S. (2014) Western Empires, Christianity and the Inequalities Between the West and the Rest 1500-2010. Johannesburg: Penguin Books.

Wallerstein, I. (2004) Uncertainties of Knowledge. Philadelphia: Temple University Press. 
Publisher's Note Springer Nature remains neutral with regard to jurisdictional claims in published maps and institutional affiliations. 